\title{
Solid waste management plan of pharmacy faculty in Karachi university
}

\author{
Mursaleen Usmani *, Abdul Wahab, Hafsa Sultana \\ Institute of Environmental studies, University of Karachi, Pakistan \\ *Corresponding author E-mail: mursaleen_usmani@yahoo.com
}

Copyright (c) 2014 Mursaleen Usmani et al. This is an open access article distributed under the Creative Commons Attribution License, which permits unrestricted use, distribution, and reproduction in any medium, provided the original work is properly cited.

\begin{abstract}
Solid waste is considered as a biggest pollution problem in Pakistan. Improper management of solid waste creates many problems in Pakistan like health problems by causing different disease; create unpleasant smell, land pollution and also effect the beauty of the country. The country spends lot of income for the management of solid waste. The aim of this research is to identify that solid waste is consider as an economic burden or an economic assets. For this research work, we choose the pharmacy faculty found in university of Karachi, Pakistan. We collect different type of data related with solid waste from the members of the faculty and the result of the project shows that our little effort can make lower this burden and we can convert this economic burden into economic assets.
\end{abstract}

Keywords: Segregation, Bring System, Composting, Questionnaires, Dumping Site.

\section{Introduction}

Waste management is considered as the generation, prevention, characterization, treatment, reuse and residual disposition of solid wastes. There are various types of solid waste generate from municipal, agricultural, health care, industries and many other places. These waste produced by human activity or some other activities. Proper management of these waste reduce their effect on health, on the environment or aesthetics. Some country considered that solid waste management is an economic burden, the aim of this research is to identify that solid waste is consider as an economic burden or an economic assets. For this work we choose the pharmacy faculty found in university of Karachi, Pakistan. Our objective is to calculate the total amount of solid waste generated in pharmacy faculty per day, week, monthly, yearly and what type of solid waste generating there, what are the properties of that waste that are of economic value? We collect different type of data related with solid waste from the members of the faculty by questionnaire system.

Waste is generating from many sources, one of the type is classify as municipal solid waste. It is described as the waste that is produced from residential, commercial and institutional sources with the exception of hazardous and universal wastes [9]. Another class of the waste is known as hazardous waste. Hazardous wastes are substances which are potentially hazardous to human health and/or the environment. This type of waste requires special disposal techniques to eliminate or reduce the hazards [3]. Different type of places and firm produce different type of waste such as Commercial and institutional firms typically produce waste as a result of conducting trade and business [6], whereas the waste streams of industrial firms (manufacturing, repair, production) are typically characterized as liquid wastes, solid wastes, or air pollutants with each typically being managed and regulated differently [11]. The three R's are commonly used terms in waste management; they stand for "reduce, reuse, and recycle". As waste generation rates have risen, processing costs increased, and available landfill space decreased, the three R`s have become a central tenet in sustainable waste management efforts [1], [5], [8], [10].

For the waste management, different type of method has been used all over the world. Waste management methods cannot be uniform across regions and sectors because individual waste management methods cannot deal with all potential waste materials in a sustainable manner [7]. Waste management systems must remain flexible in light of changing economic, environmental and social conditions [2], [4]. In this research work the method of waste management has done through survey questioning that is described below. 


\section{Survey question}

Some relevant questions asked by the staff, workers, sweepers \& students of the pharmacy faculty.

- What is the total population of pharmacy faculty?

Answer) average population 1600

- How many sweepers available here?

Answer) total 6 sweepers, 4 in the morning and 2 in evening

- What is the salary of each sweeper?

Answer) $17000 \mathrm{Rs} /$ month of morning sweeper

2500/month Rs of evening sweeper

- Is dustbin facility available in each class room?

Answer) yes

- Segregation of solid waste (different type of solid waste collect separately in different containers) available?

Answer) not done

- Which type of solid waste generate in high quantity?

Answer) mostly cardboard (like slice juice box) \& plastic wrappers.

- Where the solid waste is being dumped after transferring into dustbin?

Answer) dumping site which is found in the middle of this faculty.
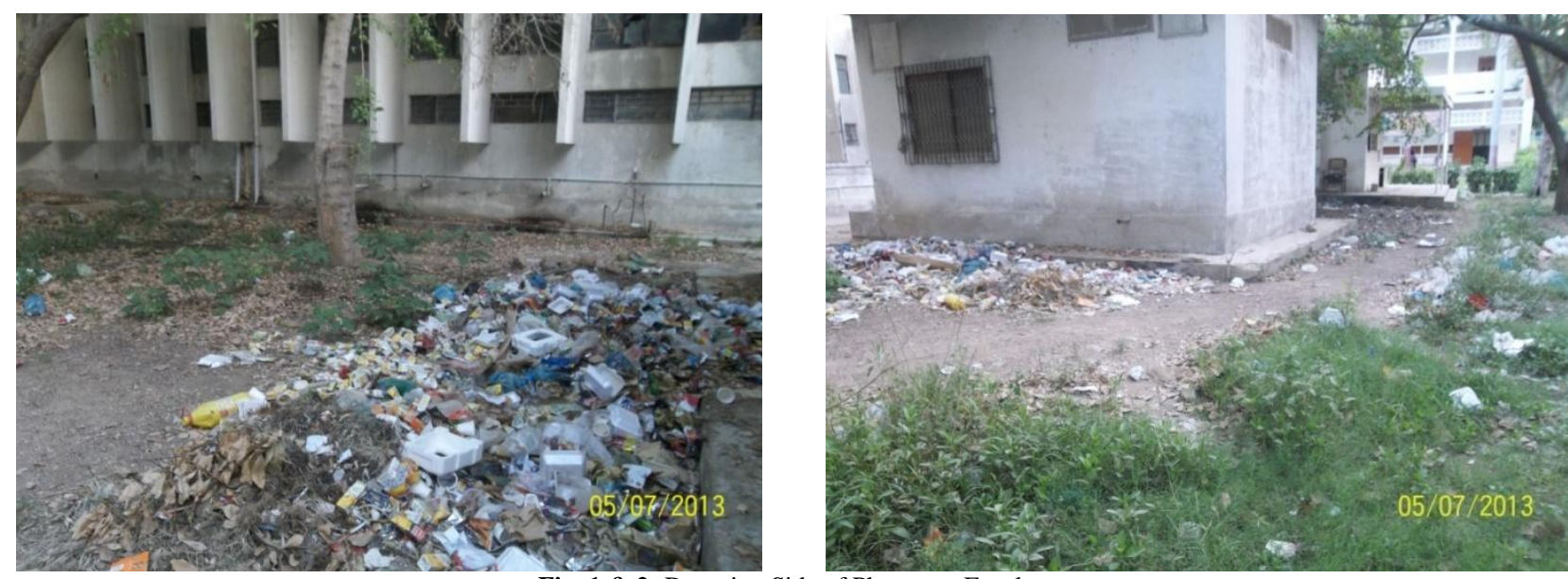

Fig. 1 \& 2: Dumping Side of Pharmacy Faculty

- Is any truck available for collect solid waste from this dumping side?

Answer) yes

- How many trucks available? \& how many times they come?

Answer) 1 truck available, 1 round in a day and 2 times come in a week, total 2 round in a week \& 8 rounds in a month.

- Which type of truck?

Answer) open truck

- Where is the dumping side of this truck?

Answer) at dumping side near back side of university graveyard.

- What is the method of disposal?

Answer) open burning

- What is the salary of truck person?

Answer) average $15000 \mathrm{Rs} / \mathrm{month}$

Some other information related to solid waste management is;

- $\quad$ Origin of waste:

Institutional (controlled waste)

- Form:

Solid

\section{Result and discussion}

\subsection{Economy spends related with solid waste in pharmacy faculty}

Total 6 sweepers

4 in the morning, each sweeper earns RS 17000/month, so total earning of 4 sweepers would be RS 68000/month. 
2 in the evening, each sweeper earn RS 2500/month, so total earning of 2 sweepers would be RS 5000/month.

The total salary of all sweepers in pharmacy faculty is RS 73000/month

Per Labor cost for each truck RS 15000/month

Total 8 trips of dumping site in a month,

The truck goes average $2 \mathrm{~km}$ to dumping site near university graveyard.

$1 \mathrm{~km}$ fuel price RS 103.6, so $2 \mathrm{~km}$ price is 207.2

For 8 trips RS 1658/month

Table 1: The Total Economy Spend Related with Solid Waste from Pharmacy Faculty

\begin{tabular}{ll}
\hline Economy spend & RS/month \\
\hline Sweepers & 73000 \\
truck person & 15000 \\
fuel price & 1658 \\
Total & 89658 \\
\hline
\end{tabular}

Total finances related with solid waste are;

RS 89658/month

RS 2989/day

RS 1075896/year

Table 2a \& 2b: Types and Quantity of Solid Waste Generated in Pharmacy Faculty

\begin{tabular}{lc}
\hline Total quantity of solid waste & Kilogram \\
\hline Generate/day & 24.1 \\
Generate/week & 168.7 \\
Generate/month & 723 \\
Generate/year & 8676 \\
\hline
\end{tabular}

Table $2 \mathrm{a}$

\begin{tabular}{llll}
\hline Types & Kg/day & Kg/week & Kg/month \\
\hline Paper & 5.2 & 36.4 & 156 \\
Cardboard & 9 & 63 & 270 \\
Plastic & 8.3 & 58.1 & 249 \\
Metal & 0.3 & 2.1 & 9 \\
Glass & 0.5 & 3.5 & 15 \\
cotton \& food waste & 0.8 & 5.6 & 24 \\
Total & $24.1 \quad$ & 168.7 & 723 \\
\hline
\end{tabular}

Table 3: Economic Value of Waste Material and Total Economic Benefit

\begin{tabular}{lll}
\hline Rate for sold/Kg & Quantity generated * sell price/Kg & cost/day \\
\hline paper 15 & $5.2 * 15$ & 78 \\
plastic 25 & $8.3 * 25$ & 207.5 \\
metal 25 & $0.3 * 25$ & 7.5 \\
glass 4 & $0.5 * 4$ & 2 \\
cardboard 5 & $9 * 5$ & 45 \\
\hline
\end{tabular}

\begin{tabular}{llll}
\hline Total Economic benefit & RS 340/day & RS 10200/month & RS 122400/year \\
\hline
\end{tabular}

Minor amount of food \& agriculture waste (leaves, outer covering of fruits) can be used for composting. 


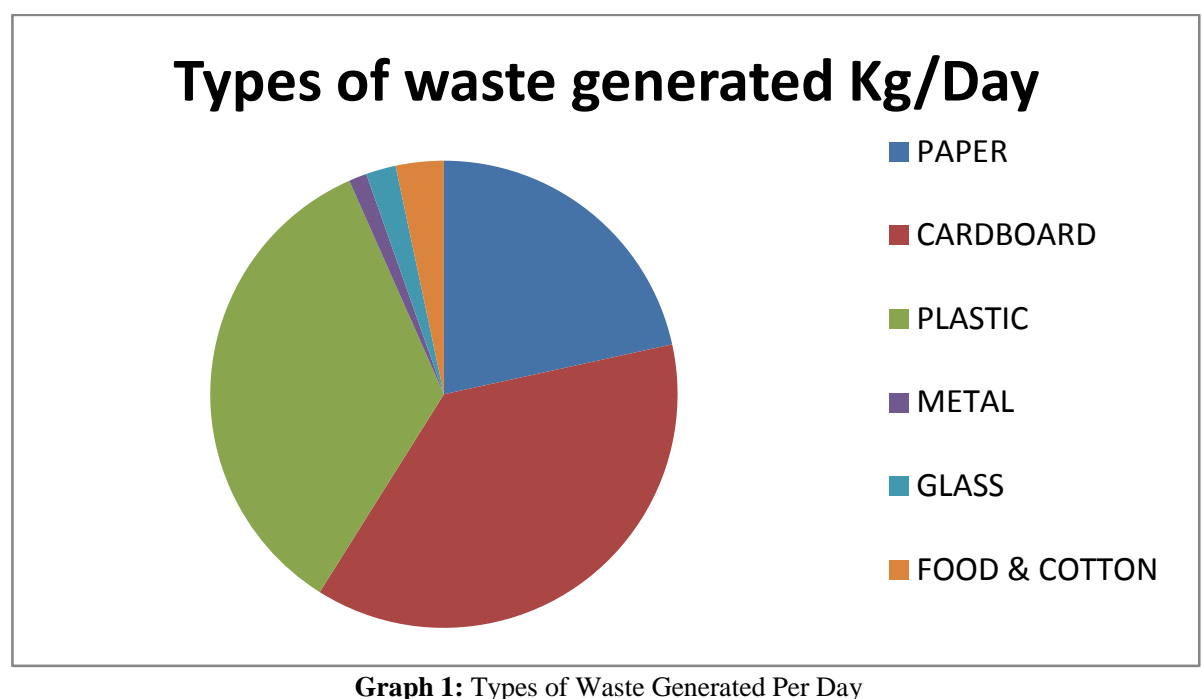

\subsection{Method of disposal use}

Open burning, open dumping

\subsection{Key of a successful planning \& management for solid waste:}

1) Remove compostable material(biological waste)

2) Remove recyclable material(paper, plastic, glass etc)

3) Remove combustible.

\subsection{Short term health issue in pharmacy faculty}

1) aesthetic

2) odors

\section{Recommendation}

- Apply segregation: each different type of solid waste should be separately collected in different container. This is a key to success for solid waste management.

- $\quad$ Reuse \& recycle the valuable material \& get economic benefit.

- Use color coded container system separately for different type of waste, due to this different waste easily be manage \& classify like blue color container for glass, gray for paper etc.

- Do not use the open truck for waste transport because the garbage is uncovered in it.

- Do not use the open burning disposal method because it has lots of disadvantages, one of the biggest limitation is that it release enormous toxic gases like furans, dioxins etc.

- $\quad$ Use incineration or deep burial type method to dispose your solid waste.

\section{Conclusion}

The result of the study shows that we can convert economic burden of solid waste management into economic assets by our little effort. If we proper manage and sort our waste, reuse and sell the recyclable material so we get lot of economic benefit from this management.

\section{References}

[1] El-Haggar, S. M. (2007). Sustainable industrial design and waste management: Cradle-to-cradle for sustainable development, $424-425$.

[2] McDougall, F. R., White, P. R., Franke, M., \& Hindle, P. (2001). Integrated solid waste management: a life cycle inventory, (2), 544.

[3] Meakin, S. (1992). Hazardous waste management: Canadian directions. Government of Canada.

[4] Scharfe, D. (2010). Integrated Waste Management Plan. Centre \& South Hastings Waste Services Board/Waste Diversion Ontario and Stewardship Ontario.

[5] Seadon, J. K. (2006). Integrated waste management-looking beyond the solid waste horizon. Waste management, 26(12), 1327-36. http://dx.doi.org/10.1016/j.wasman.2006.04.009.

[6] Smith, P., \& Scott, J. (2005). Dictionary of water and waste management, Amsterdam: Elsevier Butterworth-Heinemann, (2). 
[7] Staniškis, J. (2005). Integrated Waste Management: Concept and Implementation. Environmental research, engineering and management, $3(33), 40-46$.

[8] Suttibak, S. \& Nitivattananon, V. (2008). Resources, Conservation and Recycling Assessment of factors influencing the performance of solid waste recycling programs. Conservation And Recycling, 53, 45-56. http://dx.doi.org/10.1016/j.resconrec.2008.09.004.

[9] Tchobanoglous, G., \& Kreith, F. (2002). Handbook of solid waste management, (2), 950.

[10] Tudor, T., Robinson, G., Riley, M., Guilbert, S., \& Barr, S. (2011). Challenges facing the sustainable consumption and waste management agendas: perspectives on UK households. Local Environment, 16(1), 51-66. http://dx.doi.org/10.1080/13549839.2010.548372.

[11] Woodard \& Curran Inc. (2006). Industrial waste treatment handbook, (2), 532. 